\title{
Ctenium bennae (Poaceae; Chloridoideae), a new rheophytic species from Guinea-Conakry
}

\author{
Martin Xanthos ${ }^{1}$, Gbamon Konomou ${ }^{2}$, Pepe M. Haba ${ }^{3}$ \& Xander M. van der Burgt ${ }^{1}$
}

Summary. Ctenium bennae Xanthos is described and illustrated as the only rheophytic species in the genus. The new species is known from a single waterfall on the Benna Plateau, at the border between Forecariah and Kindia Prefectures in Guinea Conakry. Ctenium bennae is here assessed as Near Threatened according to the categories and criteria of IUCN.

Key Words. Africa, rheophyte, taxonomy.

\section{Introduction}

The genus Ctenium Panz. (Chloridoideae: Cynodonteae) comprises c. 20 species, all occurring in the tropics and subtropics (Longhi-Wagner \& Cope 2014). Its distribution straddles between Africa, Madagascar and the Neotropics, although neither continent has any species in common, which makes it of particular interest to phytogeographers (Longhi-Wagner \& Cope 2014). The genus is readily distinguished from other genera in the tribe by the presence of a dorsal awn on the upper glume and imperfect florets above and below a perfect floret. The first synopsis of Ctenium was by Smith (1896) who only revised the American taxa and recognised eight species. This number has now risen to fourteen (LonghiWagner 2005) with an updated revision of the American species currently in preparation (Longhi-Wagner, pers. comm.). Clayton (1963) revised the genus for Africa and also recognised eight species. An updated revision on the African species was published by Longhi-Wagner \& Cope (2014) who formally recognised eight species.

During a seed collecting expedition to Benna Plateau, Guinea, West Africa in 2019, the second author collected a specimen (Konomou 657) of Ctenium that proved difficult to key out to species. The plant was found growing on rocks on a waterfall in gallery forest (Fig. 1). This waterfall was one of several points of interest spotted on Google Earth in preparation for the expedition to the plateau. The waterfall was revisited later in 2019 by the third and fourth authors, but only a sterile collection of the Ctenium could be made. Konomou 657 is unique in Ctenium in its combination of the two lowermost florets being completely reduced to awns, and the fourth floret absent. It also represents the only known rheophytic species of Ctenium. All other species in Africa are associated with savannas on dry sandy soils, rocky slopes or at most sandy riverbanks (Longhi-Wagner \& Cope 2014). In the neotropics, species occur in similar habitats, mainly cerrado and campo rupestre (LonghiWagner \& Renvoize 2004). Konomou 657 represents the only fertile collection to date and the plant is described below as new.

\section{Materials and Methods}

All specimens cited have been seen by the authors. The conservation assessment was made using the categories and criteria of the IUCN red list (IUCN 2012) and the guidelines for their use (IUCN 2019). Konoumou 657 was compared with specimens of Ctenium at $\mathrm{K}$ that were named or verified by Hilda Longhi-Wagner - a specialist in the genus. In particular, sheets were examined of the variable species C. newtonii Hack. Images of Ctenium from 'JSTOR' were also compared in the same way. Spikelets from Konomou 657 were examined using a Leica S6E dissecting binocular microscope at $40 \times$ magnification.

Ctenium bennae Xanthos sp. nov. Type: Guinea Conakry, border between Forécariah and Kindia Prefectures, slopes of Benna Plateau above Gombokori Village, 944'40.5”N, 1249'47.3”W, 780 m, 12 Feb. 2019, Konomou 657 (holotype K [K001418296]; isotypes BR, ETH, G, HNG, MO, P, WAG).

http://www.ipni.org/urn:lsid:ipni.org:names:77220435-1

Caespitose perennial, 1 - $1.1 \mathrm{~m}$ without a rhizome. Leaf sheaths glabrous, papery; ligule $1 \mathrm{~mm}$ long,

\footnotetext{
Accepted for publication 6 September 2021. Published online 3 November 2021

1 Herbarium, Royal Botanic Gardens, Kew, Richmond, Surrey, TW9 3AE, UK. e-mail: m.xanthos@kew.org

2 Herbier National de Guinée, Université Gamal Abdel Nasser, Conakry, Guinea.

3 Guinée Biodiversité, Conakry, Guinea.
} 
membranous; leaf blades convolute, occasionally flat, 20 $-30 \mathrm{~cm} \times 1.5-5 \mathrm{~mm}$, glabrous. Spikes $3-7,11-15 \mathrm{~cm} \times 3$ $-4 \mathrm{~mm}$; peduncle puberulous, often bearded at the base of the spike with hairs up to $0.5 \mathrm{~mm}$ long; rachis glabrous or shortly ciliate on the back and margins with cilia less than $0.25 \mathrm{~mm}$ long. Spikelets $3.5-4 \mathrm{~mm}$ long, bearded at the base with white hairs, 3-flowered. Lower glume $2.5 \times$ $0.5 \mathrm{~mm}$, translucent, 1-nerved, apex acute. Upper glume $4.5-5 \times 0.5 \mathrm{~mm}$, 2-nerved, shortly hirsute all over, papillose on the lateral nerve and midrib, dorsal awn $2-$ $3 \mathrm{~mm}$ long, apex attenuate to acuminate, sometimes appearing slightly unequally bifid. First floret completely reduced to an awn $\pm 1.1 \mathrm{~cm}$, antrorsely scabrous. Second floret completely reduced to an awn, $\pm 1 \mathrm{~cm}$, antrorsely scabrous. Third floret well-developed; lemma $3.5 \times 1 \mathrm{~mm}$, with a dorsal awn $\pm 1.1 \mathrm{~cm}$ long, antrorsely scabrous, 3nerved, narrowly lanceolate, glabrous, apex acute to acuminate, translucent, ciliate on the margins, these hairs up to $1 \mathrm{~mm}$ long, white; palea similar to the lemma, $3.5 \times 0.7 \mathrm{~mm}$, 1-nerved; stamens not seen. Caryopsis $1.9-$ $2 \times 0.5 \mathrm{~mm}$, olive-green with white apex. Fourth floret absent. (Fig. 2).

RECOGNITION. Ctenium bennae has the most reduced spikelet structure among the African species of Ctenium, with the first two florets reduced completely
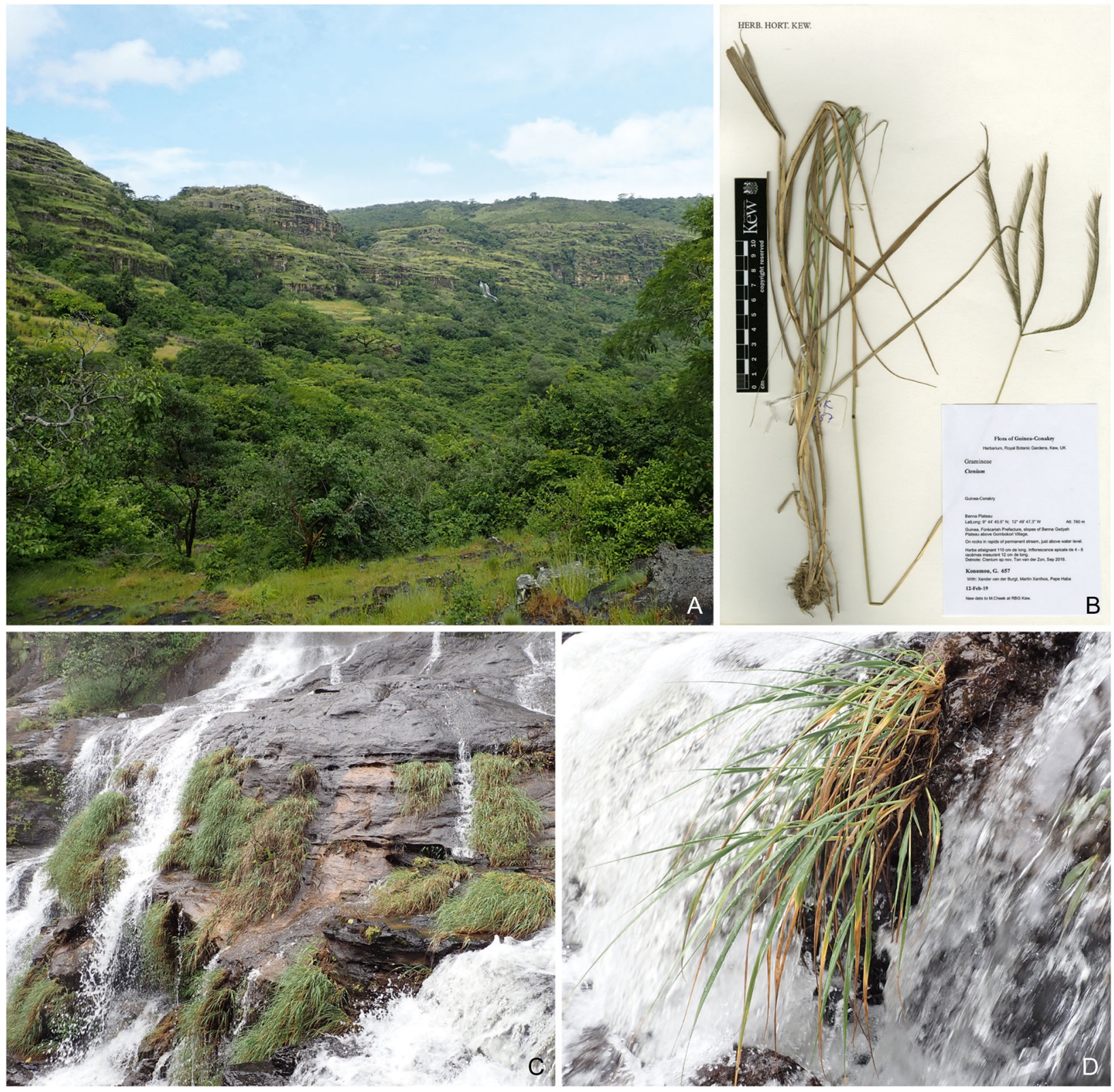

Fig. 1. Ctenium bennae. A the species was only found in the waterfall seen in the distance, 5 Nov. 2019; B unmounted herbarium specimen of Konomou 657; C habitat, sandstone rocks in the rapids of a permanent stream, 2 Nov. 2019; D close up of the species growing in the rocks, 2 Nov. 2019. PHOTOS A, C, D XANDER VAN DER BURGT, B MARTIN XANTHOS. 


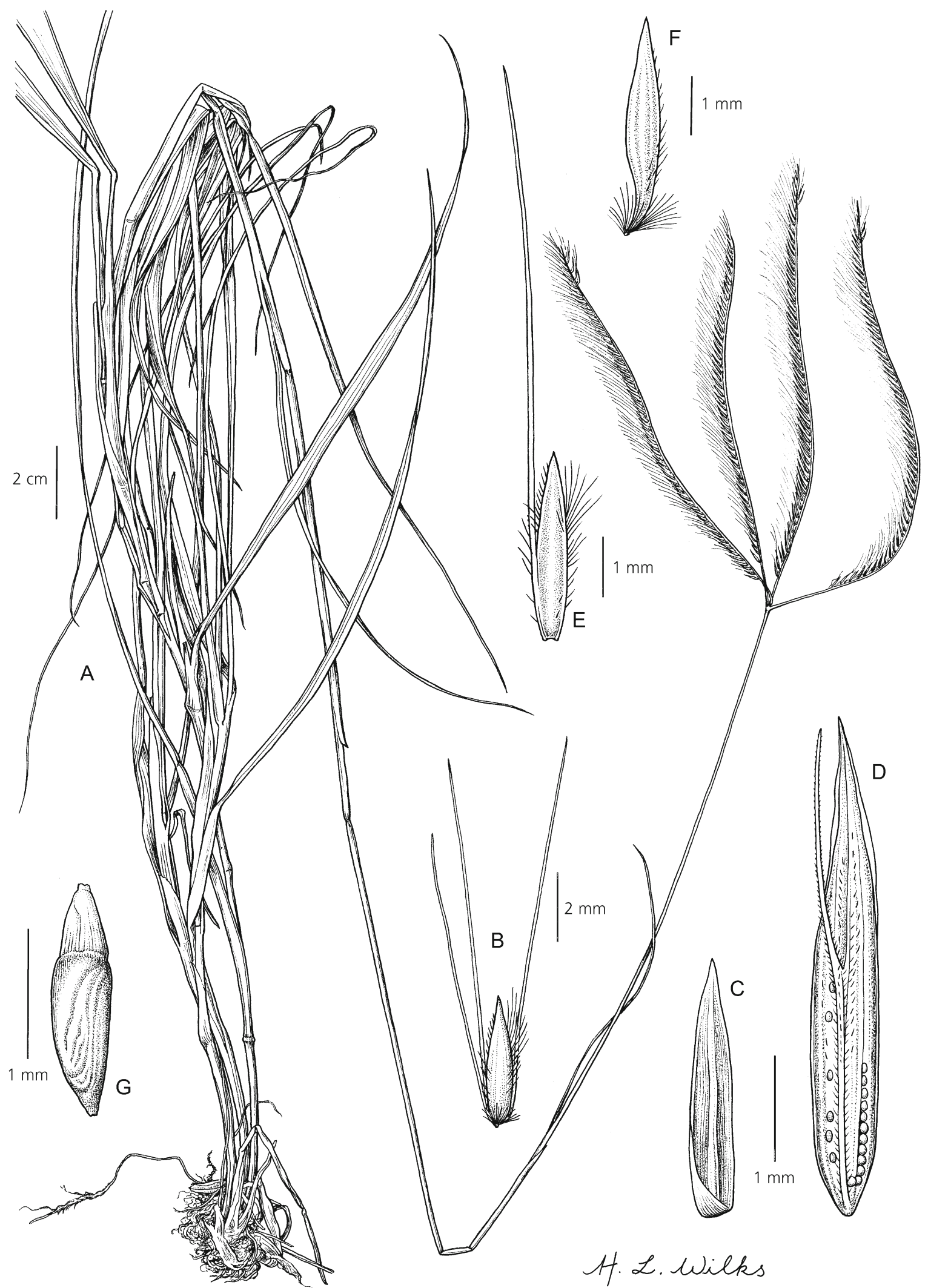

Fig. 2. Ctenium bennae. A habit; B spikelet with glumes removed; C lower glume; D upper Glume; E third lemma; F third palea; $G$ caryopsis. From Konomou 657. DRAWN BY HAZEL WILKS. 
to awns (i.e. lemma body absent) and the fourth floret absent. Only the third floret is fully developed. Affinities occur with $C$. sesquiflorum but this has the first and fourth floret absent and the presence of a second rudimentary lemma. Specimens of C. newtonii var. newtonii at $\mathrm{K}$ have been recorded with no fourth floret but even these specimens have rudimentary first and second lemmas, and the inflorescence has 1 spike; not $3-7$ as in $C$. bennae. The species is the only rheophytic representative in the genus. A comparison of $C$. bennae with morphologically similar species from West Africa is given in Table 1.

DISTRIBUTION. Ctenium bennae occurs in Guinea-Conakry, border between Forécariah and Kindia Prefectures, on the slopes of Benna Plateau above Gombokori Village (Map 1).

SPECIMENS EXAMINED. GUINEA-CONAKRY. Forécariah Préfecture, slopes of Benna Plateau above Gombokori Village, on rocks in rapids of permanent stream, just above water level, sterile, 2 Nov. 2019, Burgt E Haba 2337 (BR, G, HNG, K, MO, P, WAG).

HABITAT. Ctenium bennae is a rheophytic species collected on rocks in the rapids of a permanent stream that flows over sandstone bedrock in gallery forest.

CONSERVATION STATUS. Ctenium bennae is known only from one site, the type locality, Benna Plateau. There are currently no discernible threats to this site, however a single threatening event could eliminate this species globally. The Area of Occupancy (AOO) is $4 \mathrm{~km}^{2}$, which was calculated using GeoCat (Bachman et al. 2011) using $2 \times 2 \mathrm{~km}^{2}$ grid cells. Assessed against the guidelines for IUCN, this species does not quite meet the threshold for threatened taxa and is here assessed as Near Threatened (NT).

ETYMOLOGY. The epithet is named after the type locality of the species, Benna Plateau.

NOTES. The representation of the first and second floret by awns only, and the absence of a fourth floret is a combination of characters not found in any other species of Ctenium. Reduced spikelet structures are not uncommon in other species of
Ctenium. For example, C. newtonii var. newtonii usually has no fourth floret but this is not consistent throughout the variety. Longhi-Wagner \& Cope (2014) commented on the morphological variation of the spikelet in $C$. newtonii s.l. noting the difference in number of florets per spikelet and differences in dimensions of floret parts across varieties. Collections of $C$. newtonii s.l., examined at $\mathrm{K}$, sometimes have a vestigial first and second lemma but even these have some semblance of a lemma body. C. newtonii s.l. may represent a 'species complex' but it is consistent in its oneracemed inflorescence, whereas C. bennae has 3-7 racemes. It is therefore highly unlikely that this species would form a part of the C. newtonii complex. Nevertheless, more material of $C$. bennae is needed to get a better representation of its range, particularly given the fact that its habitat sets it apart from others in the genus that are found in open savannas and grasslands.

The botanical exploration of the plateau is perhaps most associated with the French botanist Henri Jacques-Félix who described many new species from this area such as Cailliella praerupticola Jacq.-Fél. (Melastomataceae; Jacques-Félix 1938) and Rhytachne perfecta Jacq.-Fél. (Poaceae; JacquesFélix 1954). In the gallery forest next to the waterfall where Ctenium bennae was found, several trees of Calophyllum africanum Cheek \& Q.Luke (Clusiaceae; Cheek \& Luke 2016) were recorded. This species was described from only the type locality in Mali but is now also known from three sites in Guinea.

The Benna plateau is part of an expanse of sandstone plateaus that covers much of Coyah, Kindia and Dubreka Prefectures and is a mix of farmland and rainforest remnants occupying the valleys and annually burned savanna occurring on the slopes and summits. To the south of Benna Plateau is the Kounoukan Massif, also part of the expanse of sandstone plateaus, where new discoveries

Table 1. Comparison of the main characteristics of Ctenium bennae, C. newtonii and C. sesquiflorum, the last two based on Longhi-Wagner \& Cope (2014).

\begin{tabular}{|c|c|c|c|}
\hline & C. bennae & C. newtonii s.l. & C. sesquiflorum \\
\hline $\begin{array}{l}\text { Spikes per } \\
\text { inflorescence }\end{array}$ & $3-7$ & 1 & $2-5$ \\
\hline Rachis & glabrous or shortly ciliate & glabrous to scabrid & densely scabrid \\
\hline First floret & represented by an awn only & barren — reduced to a lemma & absent \\
\hline Second floret & represented by an awn only & reduced to a lemma or with a single stamen & $\begin{array}{l}\text { reduced to a poorly developed } \\
\text { lemma }\end{array}$ \\
\hline Third floret & well-developed & well-developed & well-developed \\
\hline Fourth floret & absent & well-developed & rudimentary or absent \\
\hline Habitat & rainforest in permanent streams & savannas with sandy soils & high altitude sandstone plateaus \\
\hline
\end{tabular}




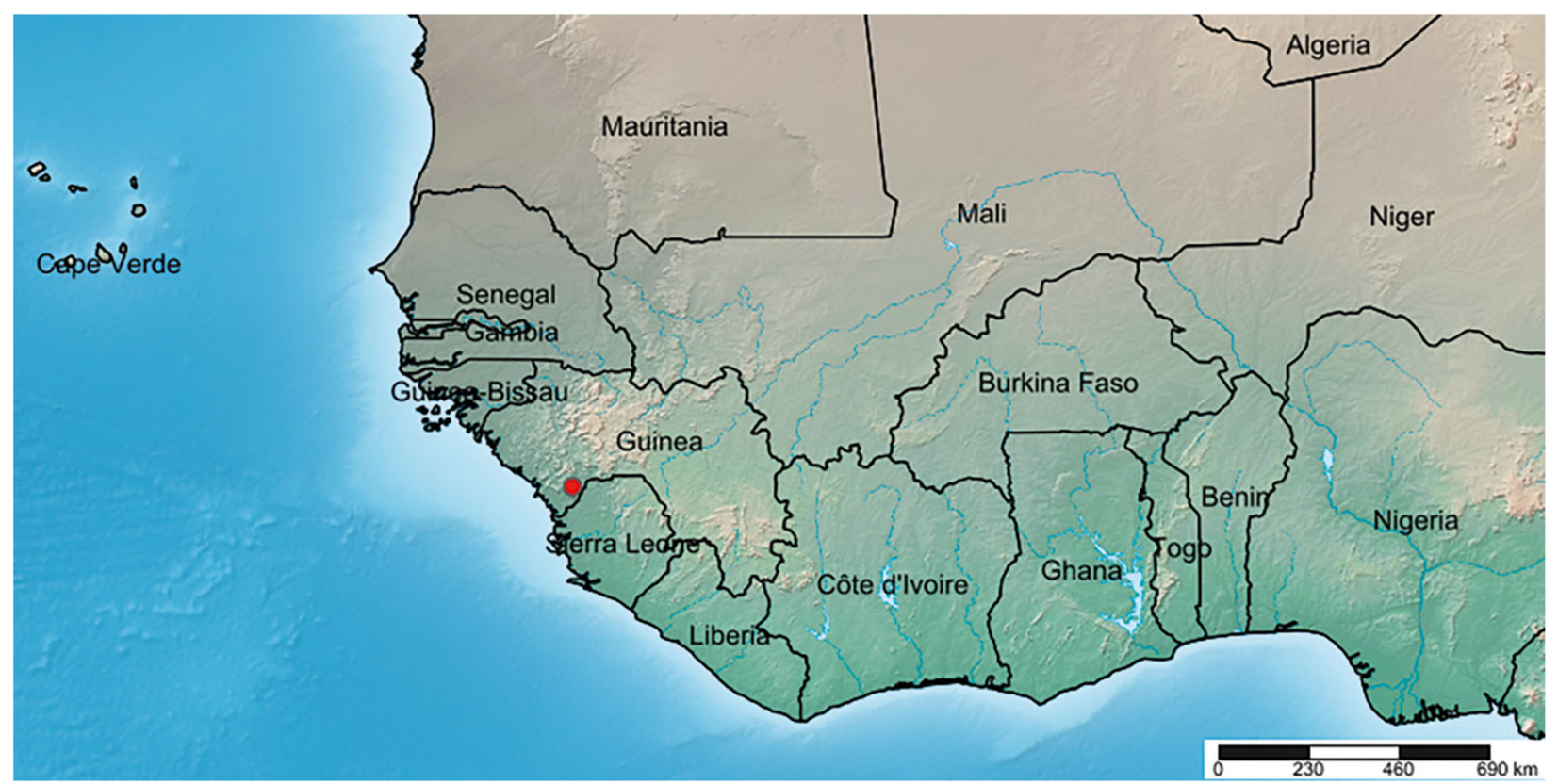

Map 1. Distribution of Ctenium bennae (๑) in Africa.

continue to be made e.g. Ternstroemia guineensis Cheek (Ternstroemiaceae: Cheek et al. 2019) and Trichanthecium tenerium Xanthos (Poaceae; Xanthos et al. 2020). The Kounounkan Massif and Plateau represents an area rich in endemic species and is proposed as a Tropical Important Plant Area or TIPA (Darbyshire et al. 2017; Couch et al. 2019). The precise location of the Benna Plateau had not yet been discovered when Couch et al. (2019) was published, and therefore the Benna Plateau is not listed as a TIPA in that publication.

\section{Acknowledgements}

The Garfield Weston Foundation funded the 'Global Tree Seed Bank Project' of Kew's Millennium Seed Bank Partnership, enabling five expeditions to Guinea. This resulted in the collection of seeds of a number of rare trees and shrubs, as well as in the discovery of some new plant species. Mr Abdoulaye Yéro Baldé, Ministre, Guinean Ministère de l'Enseignement Supérieur et de la Recherche Scientifique, and Dr Binko Mamady Touré, Secrétaire Général of the same Ministry, are thanked for cooperation. Colonel Namory Keita, Directeur, Direction National des Eaux et Forêts and Mr Mamadou Bella Diallo, Point Focal CITES, Direction National des Eaux et Forêts authorised the export of the plant and seed specimens. The first author thanks Dr A. P. M. van der Zon, Dr T. A. Cope and Dr H. M. LonghiWagner for helpful discussion on Ctenium and Hazel Wilks for preparing the illustration.
Open Access This article is licensed under a Creative Commons Attribution 4.0 International License, which permits use, sharing, adaptation, distribution and reproduction in any medium or format, as long as you give appropriate credit to the original author(s) and the source, provide a link to the Creative Commons licence, and indicate if changes were made. The images or other third party material in this article are included in the article's Creative Commons licence, unless indicated otherwise in a credit line to the material. If material is not included in the article's Creative Commons licence and your intended use is not permitted by statutory regulation or exceeds the permitted use, you will need to obtain permission directly from the copyright holder. To view a copy of this licence, visit http://creativecommons.org/ licenses/by/4.0/.

\section{References}

Bachman, S., Moat, J., Hill, A. W., de la Torre, J. \& Scott, B. (2011). Supporting Red List threat assessments with GeoCAT: geospatial conservation assessment tool. In: V. Smith \& L. Penev (eds), eInfrastructures for data publishing in biodiversity science. Zookeys 150: 117 - 126.

Cheek, M. \& Luke, Q. (2016). Calophyllum (Clusiaceae: Guttiferae) in Africa. Kew Bull. 71: 20.

, Haba, P. M., Konomou, G. \& Burgt, X. M. van der (2019). Ternstroemia guineensis (Ternstroemiaceae), a new endangered cloudforest shrub with neotropical affinities from Kounounkan, 
Guinea, W Africa. Willdenowia 49: 351 - 360. https://doi.org/10.3372/wi.49.49306

Clayton, W. D. (1963). The African species of Ctenium. Studies in the Gramineae IV. Kew Bull. 16: 471 475 .

Couch, C., Cheek, M., Haba, P. M., Molmou, D., Williams, J., Magassouba, S., Doumbouya, S. \& Diallo, Y. M. (2019). Threatened habitats and Important Plant Areas (TIPAs) of Guinea, west Africa. Royal Botanic Gardens, Kew.

Darbyshire, I., Anderson, S., Asatryan, A., Byfield, A., Cheek, M., Clubbe, C., Ghrabi, Z., Harris, T., Heatubun, C. D., Kalema, J., Magassouba, S., McCarthy, B., Milliken, W., de Montmollin, B., Nic Lughadha, E., Onana, J. M., Saïdou, D., Sârbu, A., Shrestha, K. \& Radford, E. A. (2017). Important Plant Areas: revised selection criteria for a global approach to plant conservation. Biodivers. Conserv. https://doi.org/10.1007/ s10531-017-1336-6

IUCN (2012). IUCN Red List Categories and Criteria: Version 3.1. Second edition. IUCN, Gland \& Cambridge.

(2019). Guidelines for Using the IUCN Red List Categories and Criteria: Version 14. IUCN Standards and Petitions Committee.
Jacques-Félix, H. (1938). Sur Quelques Mélastomacées Africanes. Bull. Mus. Hist. Nat. (Paris), ser. 2, 10: 630 -642 .

(1954). V. Notes sur les Graminées d'Afrique tropicale. J. Agric. Trop. Bot. Appl. 1: $41-60$.

Longhi-Wagner, H. M. (2005). New neotropical taxa in the genus Ctenium (Poaceae-ChloridoideaeCynodonteae). Kew Bull. 60: 123 - 127.

\& Cope, T. A. (2014). The genus Ctenium (Poaceae: Chloridoideae: Chlorideae) in Africa. Kew Bull. 69: 9541.

\& Renvoize, S. A. (2004). The genus Ctenium (Poaceae-Cynodonteae) in Bolivia. Kew Bull. 59: 305 $-309$.

Smith, J. G. (1896). A synopsis of the American species of Ctenium. Bot. Gaz. 21 (6): 361 - 365.

Xanthos, M., Konomou, G., Haba, P. M. \& van der Burgt, X. M. (2020). Trichanthecium tenerium (Poaceae: Panicoideae), a new species from Guinea-Conakry. Kew Bull. 75: 11.

\section{Publisher's Note}

Springer Nature remains neutral with regard to jurisdictional claims in published maps and institutional affiliations. 